\title{
Vegetation history, recent dynamics and future prospects of a Hungarian sandy forest-steppe reserve: forest-grassland relations, tree species composition and size-class distribution
}

\author{
L. Erdős ${ }^{1,3}$, C. Tölgyesi ${ }^{1}$, V. Cseh ${ }^{1}$, D. Tolnay ${ }^{1}$, D. Cserhalmi², L. Körmöczi ${ }^{1}$, \\ K. Gellény ${ }^{1}$ and Z. Bátori ${ }^{1}$ \\ 1Deparment of Ecology, University of Szeged, Közép fasor 52., H-6726 Szeged, Hungary \\ ${ }^{2}$ Department of Botany, Szent István University, Rottenbiller u. 50., H-1077 Budapest, Hungary \\ ${ }^{3}$ Corresponding author. E-mail: erdos.laszlo@bio.u-szeged.hu, Tel.: +36-20-924-78-84, Fax.: +36-62-546-949
}

Keywords: Aerial photographs, Forest-grassland ecosystem, Size-class distribution, Stability, Tree regeneration.

\begin{abstract}
Pannonian forest-steppes host a high number of endemic species and contribute to landscape-scale heterogeneity. Alterations in the proportion of forests and grasslands due to changes in land-use practice and climatic parameters can have serious nature conservation consequences. Hypotheses about forest-steppe dynamics have rarely been verified by detailed analyses, especially for the sandy forest-steppes. We integrated historical analysis, aerial photo interpretation and field investigation to determine how vegetation of a sandy forest-steppe has changed, how current dynamical processes operate and how native and exotic tree species regenerate under present conditions. The vegetation of the study area before the onset of major anthropogenic environmental transformations in the Carpathian Basin may have been a mosaic of forested and unforested patches. However, there is strong evidence that after heavy deforestation, the region was almost completely treeless between the $15^{\text {th }}$ and the $19^{\text {th }}$ centuries. Forest cover was able to recover by the 1800 s but the lack of forested areas in the region for centuries explains why forest patches are still poor in species. Grasslands, which existed continuously, are more diverse, supporting several rare and endemic species. From 1953 till 2013, 72.45\% of the area proved to be stable, but 27.55\% showed clear dynamical character, changing either from forest to grassland, or vice versa. Thus, cyclic dynamics can occur in sandy forest-steppes. We found that forest patches of different size, differently exposed edges and grasslands provide different habitats for the tree species. Exotic species were present in large numbers, probably due to the small size of the reserve and the lack of a buffer zone.
\end{abstract}

Nomenclature: Simon (2000) for species names, Borhidi et al. (2012) for plant community types.

Abbreviations: DBH-diameter at breast height, DCA-Detrended Correspondence Analysis.

\section{Introduction}

Characterized by alternating forest and grassland patches, forest-steppes form a transitional belt between the Eurasian steppes and the closed forests (Borhidi et al. 2012). The westernmost forest-steppes can be found in the Pannonian biogeographical region (Magyari et al. 2010). Due to their special position at the edge of the forest-steppe zone, they are one of the most vulnerable vegetation types in the region (KovácsLáng et al. 2000).

Since only a small proportion of the original foreststeppes has survived (Molnár et al. 2012), their role in nature conservation is extremely important. They represent unique habitats of community importance in the European Union, and host a large number of endangered and rare species (regarding the uniqueness of the sandy forest-steppes, see also Fekete et al. 2014). Knowledge on the long-term dynamics and future prospects of forest-steppes is important both from a theoretical and from a practical perspective.
Within a certain time interval a forest-grassland vegetation mosaic (1) can be stable, (2) can show cyclic dynamics or (3) can even be characterized by unidirectional changes. In the first case, both the proportion and the position of forest and grassland patches remain constant. In cyclic dynamics, forest and grassland patches replace each other in time, but the proportion of the woody and herbaceous components remains roughly the same (Jakucs 1972). If unidirectional changes happen, the proportion of one component is increasing, while that of the other is decreasing (Archer et al. 1988).

Unidirectional changes are regularly observed in several complex forest-grassland ecosystems worldwide. This, in most cases, means that woody species encroach into grasslands (e.g., Silva et al. 2001, Brook and Bowman 2006). The same process can be seen in some parts of the Pannonian biogeographical region, e.g., in loess grasslands (Somodi et al. 2004) and rock swards (Erdős et al. 2013c). Tree and shrub encroachment often results in a loss of biodiversity (Centeri et al. 2009). It has been shown for sandy forest-steppes that most of the rare, relict and endemic plants are related to open 
grasslands (Erdős et al. 2014). For example, the endangered endemic Dianthus diutinus clearly favors treeless habitats (Gál 2011). This and other valuable species would be adversely affected if the proportion of grasslands decreased due to forest expansion.

However, the reverse process, i.e., the opening up and the retreat of the forest patches, is also possible. The sandy forest-steppes of the Pannonian biogeographical region grow mostly in dry habitats. Increasing temperature, decreasing precipitation (Kertész and Mika 1999) and dropping groundwater level (Zsákovics et al. 2007) can promote grassland expansion. In fact, it has been observed that forest regeneration is deficient, mainly for Quercus species (Erdős et al. 2014). Moreover, even the survival of large trees is uncertain due to water shortage (Molnár et al. 2012). The reduction of forested areas would also be undesirable from a nature conservation perspective. Although grasslands are more unique, forest patches also support valuable species (Erdós et al. 2013b). Besides, forest patches may moderate the effects of drought events (Bartha et al. 2011), provide refuge for grassland species during extremely dry years, promote the regeneration of grasslands after disturbances (Bartha et al. 2008) and enable the existence of a distinct and diverse edge community (Erdős et al. 2014).

Thus, both the forest and the grassland components are essential for the long-term maintenance of the natural values of the sandy forest-steppes. However, no detailed analyses on the dynamics of this ecosystem have been carried out so far (cf. Haraszthy 2014). A more detailed understanding of the dynamic processes would be necessary for predictions and efficient nature conservation measures.

It has been recognized that knowledge on the history of a landscape is indispensable for the correct evaluation of the current state and processes (e.g., Molnár and Biró 2010). The usefulness of land-use historical analyses has been proven in several environments, including various types of forests (e.g., Gusev 2014), woodlands and shrublands (e.g., Duguy and Vallejo 2008), grasslands (e.g., Ödman and Olsson 2014), and highly modified artificial landscapes (e.g., Lunt and Spooner 2005). Land-use history has played an important role in shaping the present patterns of the forest-steppes, however, little is known about this topic (Bölöni et al. 2011). Detailed analyses are necessary, revealing the history of the forest-steppes for the past few hundred years. Also, knowledge on the dynamics of the previous few decades is insufficient regarding foreststeppes (Haraszthy 2014), although such information may help reveal ongoing dynamics.

The size-class structure of trees may give an insight into the history of a forest stand. Moreover, it enables to draw some tentative conclusions regarding the possible future tendencies, based on tree recruitment patterns. Recently, it has been recognized that forest-steppes are more heterogeneous than previously thought (Erdős et al. 2013a, 2014), consisting of several different habitats. It can be assumed that these habitats provide different opportunities for tree recruitment and survival, influencing vegetation dynamics, although no detailed analysis has been carried out on this topic yet.
Although the history of an area is continuous, for practical reasons, in our paper we differentiate between the vegetation history of the past millennia (for which data are scarce and sometimes uncertain), and the more recent dynamical processes of the past few decades (for which exact analyses can be done, using aerial photographs).

In this article, our first objective was to reveal the vegetation history of a forest-steppe reserve based on botanical and ethnographic data as well as on various historical sources and old maps. Our second goal was to collect information on the recent dynamic processes, using aerial photographs. Finally, we aimed to investigate the floristic composition and the size class distribution of the native and exotic tree species of the study area, with special emphasis on how tree species are able to regenerate under present conditions. Earlier hypotheses stated that sandy forest-steppes are stable, mostly because forest patches cannot expand into grasslands (Bodrogközy 1982, Fekete 1992). Based on our results, we aimed to test these hypotheses and to formulate some suggestions for efficient conservation measures that could promote the long-term survival of forest-steppe remnants.

\section{Materials and methods}

\subsection{Study area}

Our study was carried out in a 17.5 ha nature reserve near Ásotthalom (N 4612', E $\left.19^{\circ} 47^{\prime}\right)$, representing the sandy vegetation of the southeastern part of the Danube-Tisza Interfluve in Hungary (Fig. 1). Climate is semiarid (Borhidi 1993), mean annual temperature is $10.6^{\circ} \mathrm{C}$, mean annual precipitation is about $570 \mathrm{~mm}$ (Ambrózy and Kozma 1990). The area is characterized by small sand dunes. Grasslands grow on humus-poor sandy soils, while forest patches have soils of higher humus content with brown forest soils below, buried by the sand (Bodrogközy 1957, 1982).

The vegetation of the nature reserve is a mosaic, where forest patches alternate with xeric grasslands (Bodrogközy 1957). In the forest patches, canopy has a cover of $50-60 \%$, dominated by up to $15-16 \mathrm{~m}$ tall silver poplar trees (Populus $a l b a$ ). In the shrub layer (height of about 1-3 m), the most abundant species include Berberis vulgaris, Crataegus monogyna and Ligustrum vulgare. The herb layer $(5-50 \mathrm{~cm})$ is sparse, supporting some mesic plants (e.g., Dryopteris carthusiana, Geum urbanum, Hedera helix, Lithospermum officinale, Stellaria media). In the openings and on the edges, herb layer cover usually increases, and more xeric species appear (e.g., Dianthus giganteiformis ssp. pontederae, Festuca rupicola, Potentilla arenaria).

Grasslands between the forest patches are built up mainly by open swards, dominated by Festuca vaginata and Stipa borysthenica. The cover of mosses, lichens and bare soil is also considerable. Other typical grassland species are Alkanna tinctoria, Dianthus serotinus, Fumana procumbens, Iris arenaria, Onosma arenaria.

According to the most recent floristic data, a total of 15 legally protected plant species can be found in the study area 


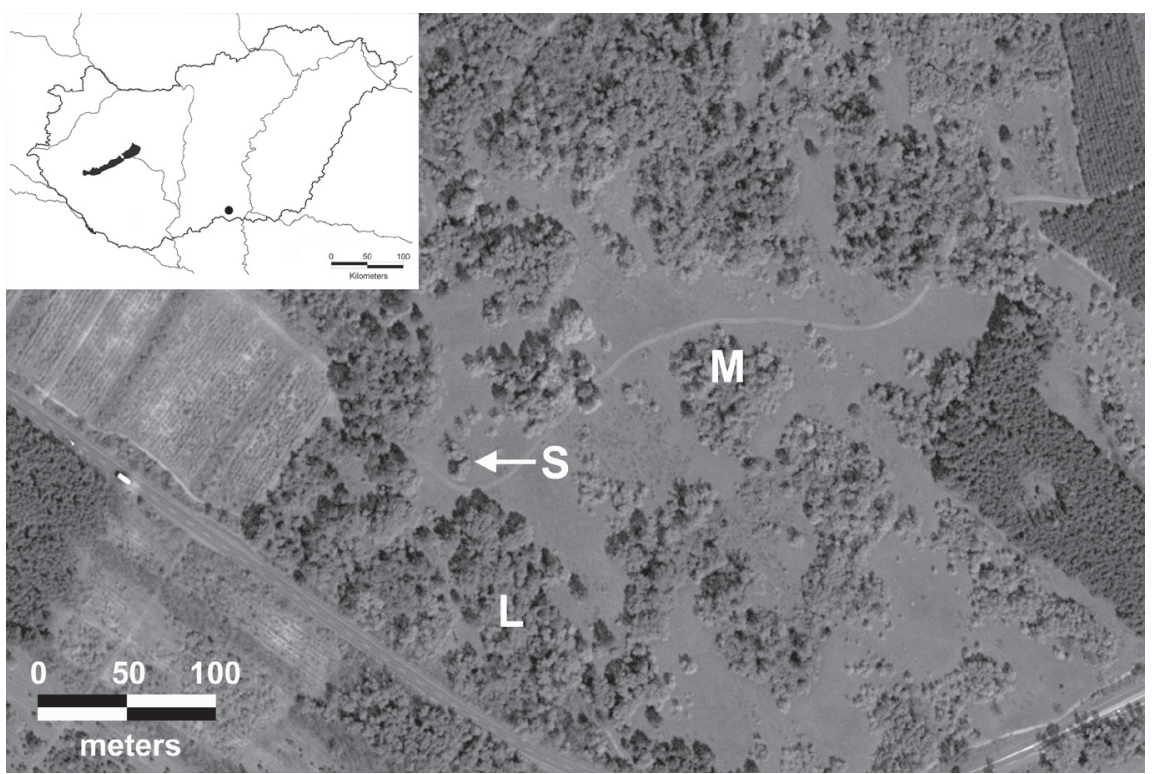

Figure 1. Forest-grassland mosaic in the study area from Google Earth, with examples for small (S), medium $(\mathrm{M})$, and large (L) forest patches. The inset shows the location of the study area in South Hungary.

(Gaskó 2009, Erdős et al. 2013b, Bátori et al. 2014), including five endemics (Colchicum arenarium, Dianthus diutinus, $D$. serotinus, Iris arenaria, Tragopogon floccosus). Two of them, Colchicum arenarium and Dianthus diutinus are included in Annex II. of the Habitats Directive of the European Union. Dianthus diutinus is classified as an endangered species on the IUCN Red List. It is restricted to the sandy region of the Danube-Tisza Interfluve, having only thirteen known localities. Population of this species in our study area consists of about 300 individuals and shows an increasing trend (Gál 2011).

\subsection{Vegetation history}

Several direct and indirect sources can be used for landscape historical analyses, such as old maps, historical documents, knowledge of local people, ethnographic and botanical data (Molnár and Biró 2010).

The history of our study area was reconstructed using the following data sources: botanical and paleobotanical data on the natural vegetation of the Pannonian biogeographical region; results of floristic, vegetation and soil surveys carried out in the study area; ethnographic data; reports, travel reports, diaries; early publications on forestry; historical maps. In the case of maps, as well as pre-1800 reports, travel reports and diaries, edited versions were used instead of original manuscripts. The date of the original manuscript is indicated in the text each time, whereas publication data can be found in the references section.

\subsection{Field work}

Our earlier studies revealed that within the forest-steppes of the Danube-Tisza Interfluve, forests, grasslands and edges have to be regarded as different habitats (Erdős et al. 2014). Moreover, south-facing edges differ considerably from northfacing edges (Erdős et al. 2013a). In addition, our preliminary studies showed that forest patches should be differentiated according to their size. Therefore, in the present examination, the following habitats have been treated separately: large forest patches (ca. 0.4-1.3 ha), medium forest patches (ca. 0.1$0.3 \mathrm{ha}$ ), small forest patches (ca. 0.005-0.09 ha), north-facing edges, south-facing edges and grasslands.

A total of 104 plots were established: 24 plots in large forest patches, 20 plots in medium forest patches, 10 plots in small forest patches, 15 plots in north-facing edges, 15 plots in south-facing edges, and 20 plots in grasslands. Plots were distributed randomly within each habitat type. All plots were $5 \mathrm{~m} \times 5 \mathrm{~m}$, except for the edge plots, which were $2 \mathrm{~m} \times 12.5$ $\mathrm{m}$, to ensure that they do not extend into forest or grassland interiors. Within each plot, all tree individuals were inventoried according to their species, and - if higher than $1.3 \mathrm{~m}-$ their diameter at breast height (DBH) was measured.

\subsection{Data analysis}

Since native and exotic trees showed an entirely different distribution, we evaluated the two groups separately. Diameter distribution of the trees was visualized using $5 \mathrm{~cm}$ diameter classes for the native trees. Stand characteristics such as mean and maximum DBH and number of trees per ha were calculated for both native and exotic species. Distributions were compared with the Kolmogorov-Smirnov test

To compare the composition of the tree species of the different habitats we carried out ordinations. Since a gradient from large forest patches to grasslands was assumed, we applied detrended correspondence analysis (DCA) (Hill and Gauch 1980), using log-transformed numbers of tree individuals. This analysis was carried out in three different ways. First, only individuals with a DBH of $0-5 \mathrm{~cm}$ were considered. Second, all tree individuals were included, but DBH classes were disregarded. Third, all tree individuals were included, using three rough DBH classes: $0-5 \mathrm{~cm}, 5-50 \mathrm{~cm},>50 \mathrm{~cm}$. Past 3.01 (Hammer et al. 2001) was used for the computation. 


\subsection{Aerial photo interpretation}

We used two aerial photographs, covering a 60 years period. The panchromatic image from 1953 was supplied by the Ministry of Defense Mapping Company. The photocopy was digitized, resulting in a ground resolution of $0.2 \mathrm{~m}$. The recent aerial photo from 2013 was exported from Google Earth with a ground resolution of $0.5 \mathrm{~m}$. Aerial photographs were handled with QGIS 2.2 Valmiera, which incorporates natively the Google Earth openlayer. The archive aerial photograph was georeferenced also in QGIS 2.2 Valmiera by associating with Google Earth layer. In both images, habitats were classified into two categories manually: forest and grassland. The areas of both types in both years were calculated. In addition, the cover of the areas showing different transitions (forest to forest, forest to grassland, grassland to grassland, grassland to forest) was determined. Analyses were performed using ArcView GIS 3.2 (ESRI).

\section{Results}

3.1 Vegetation history of the study area and its surroundings before 1950

The map of the natural vegetation of Hungary (Zólyomi 2007) shows that the vegetation of our study area and its surroundings consisted of a mosaic of sand grasslands, forest patches, marshes and saline communities. However, given the serious methodological and conceptual problems related to the potential natural vegetation (Chiarucci et al. 2010, also see Härdtle 1995, Loidi and Fernández-González 2012), Zólyomi's (2007) map should by no means be regarded as an indisputable description of the pre-human vegetation. In spite of the above uncertainties, it is generally accepted that the Great Hungarian Plain belongs to the forest-steppe zone (Kovács-Láng et al. 2000, Fekete et al. 2002, Borhidi et al. 2012). Correspondingly, its vegetation around the beginning of the intensive human activities was most probably a mosaic of forested and non-forested patches, although the proportion and the exact character of the components are unknown. The presence of a forest-steppe in the Great Hungarian Plain is supported by paleobotanical data (Magyari et al. 2010).

The megaherbivore hypothesis of Vera (2000) may also be considered in this context. Large mammals living in the Carpathian Basin during the Late Pleistocene (Kovács 2011) and the Holocene (Pazonyi 2004) might have contributed to the prevention of the development of a closed forest landscape.

It can be assumed that forest cover decreased gradually as a result of human activity (Gaskó 2009). Forest clearings became especially intensive during the last 3000 years, as shown by the paleobotanical evidence for north-eastern Hungary (Magyari et al. 2010). A similar history may be presumed for our study area as well.

Although our knowledge on pre- 1400 vegetation is rather uncertain, we do have a number of historical data from the post-1400 period. Several historical sources show that the study site and the surrounding region were mostly treeless from the $15^{\text {th }}$ century until the beginning of the $19^{\text {th }}$ century, probably due to forest clearing and livestock grazing. The first reliable data originate from Bertrandon de la Brocquiére. During his 1433 journey in the region (between Becse and Szeged), about 20-25 km southeast of our study area, he saw not a single tree except those along streams (Szamota 1891). Miklós Oláh noted in 1536 that in the region around Kiskunhalas (ca. $35 \mathrm{~km}$ away from the study area), there was a total lack of trees; therefore, inhabitants used reed for burning (Szamota 1891). Evlia Cselebi, a Turkish traveller visited the nearby town of Szabadka (located about $14 \mathrm{~km}$ from the study area) in 1665, and he found that it was surrounded by a huge treeless plain. Moreover, from the area situated a bit farther to the north, he wrote that it was a "desert" (Karácson 1908). Based on the 1719 description of the region, it can be concluded that forests must have been extremely rare or completely absent in the region, although solitary trees did occur in the landscape (Reizner 1900). In their summary originally published in 1732, Mátyás Bél and János Matolai characterized the whole region as suitable for agriculture, livestock grazing and fishing, but forestry was absent. Trees were planted only sporadically (Bél 1984). On the map of Ábrahám Kaltschmidt, prepared in 1747 , the region was extremely poor in trees, though there was a small forest some $15-20 \mathrm{~km}$ away from the study area (Farkas 1985). The geologist Inigo Born found in 1770 that between the rivers Danube and Tisza, it was possible to travel 6-7 hours without seeing a single tree, except those around settlements (Born and Ferber 1777). According to the first military survey conducted in 1783, the region was covered partly by moving sand dunes, partly by grasslands (pastures) (Ministry of Defense Map Archives 2004). A similar picture emerges from the diary of the great botanist Pál Kitaibel (Gombocz 1945). During his journey in 1800, he described the region near Szabadka (a town $14 \mathrm{~km}$ from our study area) as an area consisting of bare sand surfaces, pastures, vineyards, tobacco plantations, ploughlands, Prunus spinosa shrubs between cultivated fields, swamps and a lake. The occurrence of forests was not mentioned, but he added that firewood was transported from other regions.

Fundamental changes in the vegetation of the study area took pace in the first half of the $19^{\text {th }}$ century: the cover of woody vegetation increased considerably at the expense of grasslands. By the time of the botanical surveys of Anton Kerner (1863), Populus alba, P. nigra and P. tremula had become widespread in the region, even in sandy areas located far away from rivers. Also, he found oak forests interspersed by grasslands. Beside native forests, he noted that there was an increasing amount of Pinus, Robinia pseudo-acacia and Populus plantations. Forests were usually grazed. In 1866 and 1884 , as indicated by the second and third military surveys, respectively, the study area was forested (Biró and Gulyás 1999, Ministry of Defense Map Archives 2005). According to Vedres (1825), Szüts (1914) and Kerkápoly (1954), forest planting started at the beginning of the $19^{\text {th }}$ century in the region. More specifically, the study area was planted in 1807, mainly with Populus nigra, but P. alba and P. tremula individuals were also added later, as indicated by the 1830 
report of the forester Szilberg (Kiss 2008). Despite the fact that mainly P. nigra was planted, Kiss $(1911,1915)$ wrote that by 1887 only a few $P$. nigra individuals had survived, and the canopy had become dominated by P. alba. By 1907, P. nigra had virtually got extinct.

Grazing had an important role in the region till the $20^{\text {th }}$ century. Historical and ethnographic studies show that in the $19^{\text {th }}$ century and in the first half of the $20^{\text {th }}$ century, grazing was done mainly by cattle and to a lesser degree by horse and sheep (Juhász 2008). However, in the study area grazing has been prohibited since 1885 (Kiss 1915), and all forestry activities ceased in 1908 (Gaskó 2009). Consequently, spontaneous vegetation development resulted in a pattern which probably resembles the natural forest-grassland mosaic (Bodrogközy 1957, Gaskó 2009, Erdős et al. 2013a). In this process, the forest opened up and the structurally and compositionally near-natural grassland vegetation was able to recover in the treeless patches. The detailed studies of Bodrogközy (1957) suggest that the pattern reflects the position of the original forests before intensive human impact: there is always a buried brown forest soil layer below the humus-poor sandy soils in the case of forest patches. This buried soil is absent under grassland patches.

At the beginning of the $20^{\text {th }}$ century, Lengyel (1915) compiled a list of the vascular plants of the area. A secondary data analysis, based on the coenological preference categories of Borhidi (1995), gave the following results. Of the 424 species published, $114(26.89 \%)$ were typical of natural or nearnatural xeric grasslands, while only $13(3.07 \%)$ were plants of forests (the remainings were species of marshes, mesic and alkaline grasslands, disturbed areas, or they can be related

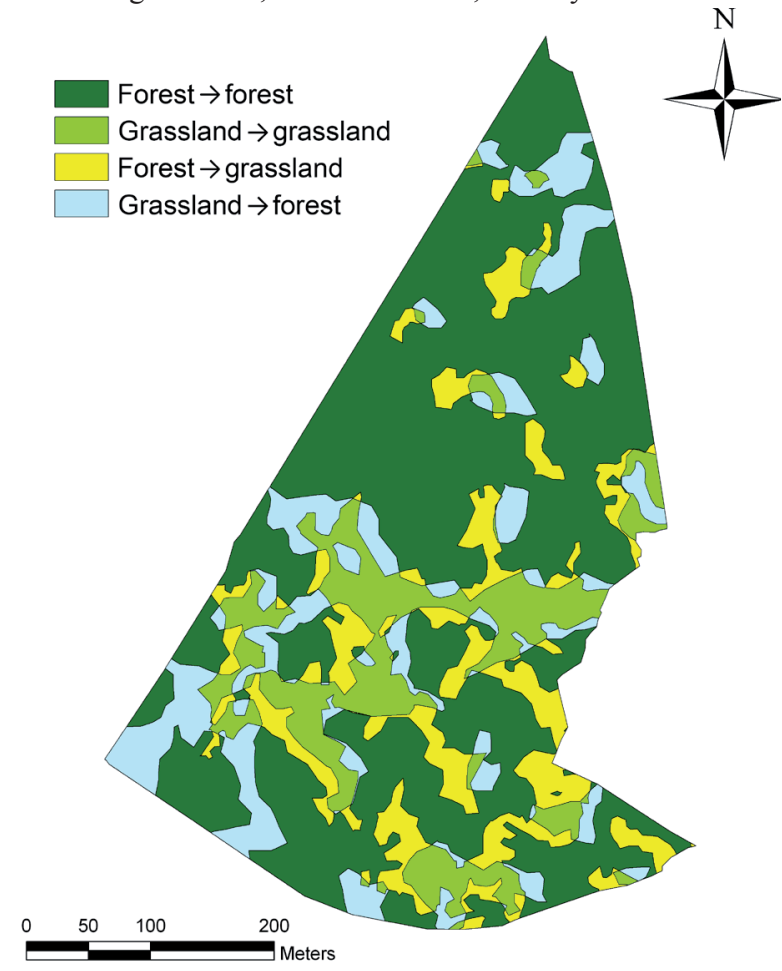

Figure 2. Changes in the forest and grassland areas in the study site between 1953 and 2013.
Table 1. Transition types of the study area between 1953 and 2013.

\begin{tabular}{lc}
\hline & \% of study area \\
\hline Stable & 72.45 \\
forest to forest & 58.94 \\
grassland to grassland & 13.51 \\
Dynamic & 27.55 \\
grassland to forest & 14.2 \\
forest to grassland & 13.35 \\
\hline
\end{tabular}

to more than one of the above categories). This probably indicates that the mostly treeless conditions of the previous centuries diminished the regional species-pool of the forestrelated plants.

\subsection{Vegetation dynamics from 1953 to 2013}

Our aerial photo analysis revealed that within 60 years, the proportion of forested areas increased from $72.29 \%$ to $73.14 \%$. Although the net change in the proportion of forests and grasslands was low, we found that there was a considerable dynamics in the study area (Fig. 2, Table 1). $27.55 \%$ of the reserve changed during the study period: $14.2 \%$ of the total study area showed a grassland-to-forest transition, while another $13.35 \%$ showed a forest-to-grassland transition. However, $72.45 \%$ of the area belonged to the same category both in 1953 and in 2013: 58.94\% of the area was and remained forest, and $13.51 \%$ was and remained grassland.

\subsection{Size class distribution and composition of the tree species in the different habitats}

According to the Kolmogorov-Smirnov test, DBH class distributions were different between two main groups: the first group included the forested habitats (large, medium and small forest patches), the second group contained the grasslands and the edges (Table 2).

Among the native tree species, Populus alba is the most frequent in the study area (Fig. 3). It clearly dominates in all DBH classes in the case of the total study area (Fig. 3a), small forest patches (Fig. 3d), north-facing edges (Fig. 3e), southfacing edges (Fig. 3f) and grasslands (Fig. 3g). Regarding large forest patches, $P$. alba dominates all but the smallest DBH classes, where Ulmus minor and Carpinus betulus are the most frequent native trees (Fig. 3b). As for the medium forest patches, $P$. alba is monodominant in all DBH classes, except for the smallest one, where Quercus robur is the most frequent among native trees (Fig. 3c).

Large forest patches harbor the biggest $P$. alba individuals (Table 3); the largest individual had a DBH of $124.78 \mathrm{~cm}$. Mean DBH and the number of large trees $(\mathrm{DBH}>50 \mathrm{~cm})$ were highest in the large forest pathes. Also, large forest patches provide habitat for the highest richness of native tree species (Carpinus betulus, P. alba, Q. robur, Ulmus minor, U. laevis). The richness of native tree species is lower in medium forest patches (Cerasus sp., P. alba, Q. robur) (Fig. 3c). In small 
Table 2. Results of the Kolmogorov-Smirnov test comparing DBH class distributions of the habitats. TSA: total study area, LF: large forest patches, MF: medium forest patches, SF: small forest patches, NE: north-facing edges, SE: south-facing edges, G: grasslands.

\begin{tabular}{|c|c|c|c|c|c|c|c|}
\hline & TSA & LF & MF & SF & $\mathrm{NE}$ & SE & $\mathrm{G}$ \\
\hline TSA & & N.S. & N.S. & N.S. & $p<0.001$ & $\mathrm{p}<0.001$ & $\mathrm{p}<0.001$ \\
\hline $\mathrm{LF}$ & & & N.S. & N.S. & $\mathrm{p}<0.001$ & $\mathrm{p}<0.001$ & $\mathrm{p}<0.001$ \\
\hline $\mathrm{MF}$ & & & & N.S. & $\mathrm{p}<0.05$ & $\mathrm{p}<0.05$ & $\mathrm{p}<0.05$ \\
\hline SF & & & & & $\mathrm{p}<0.05$ & $\mathrm{p}<0.05$ & $\mathrm{p}<0.05$ \\
\hline $\mathrm{NE}$ & & & & & & N.S. & N.S. \\
\hline SE & & & & & & & N.S. \\
\hline G & & & & & & & \\
\hline
\end{tabular}

Table 3. Some stand characteristics of the six habitats plus the total study area. TSA: total study area, LF: large forest patches, MF: medium forest patches, SF: small forest patches, NE: north-facing edges, SE: south-facing edges, G: grasslands.

\begin{tabular}{|c|c|c|c|c|c|c|c|}
\hline & TSA & LF & MF & $\mathrm{SF}$ & $\mathrm{NE}$ & SE & G \\
\hline \multicolumn{8}{|l|}{$\mathrm{DBH}<5 \mathrm{~cm}$} \\
\hline $\mathrm{N} /$ ha native trees & 1985 & 1067 & 1000 & 1720 & 1493 & 3440 & 3480 \\
\hline $\mathrm{N} / \mathrm{ha}$ exotic trees & 13181 & 29134 & 20940 & 12240 & 7013 & 1680 & - \\
\hline \multicolumn{8}{|l|}{$\mathrm{DBH} \geq 5 \mathrm{~cm}$} \\
\hline $\mathrm{N} / \mathrm{ha}$ native trees & 635 & 917 & 1420 & 1280 & 53 & 107 & 40 \\
\hline $\mathrm{N} /$ ha exotic trees & 58 & 67 & 200 & 40 & - & - & - \\
\hline mean DBH $(\mathrm{cm})$ & 32.53 & 41.29 & 29.89 & 27.85 & 18.31 & 13.85 & 9.71 \\
\hline \multicolumn{8}{|l|}{$\mathrm{DBH} \geq 50 \mathrm{~cm}$} \\
\hline $\mathrm{N} /$ ha native trees & 112 & 367 & 80 & 120 & - & - & - \\
\hline $\mathrm{N} / \mathrm{ha}$ exotic trees & - & - & - & - & - & - & - \\
\hline $\max . \mathrm{DBH}(\mathrm{cm})$ & 124.78 & 124.78 & 64.94 & 67.8 & 28.66 & 37.88 & 11.46 \\
\hline
\end{tabular}

forest patches and in edges, there are only two native species (Fig. 3d-f), while only small $P$. alba individuals are present in the grasslands (Fig. 3g).

In large forest patches, the distribution of the tree individuals among the DBH classes above $5 \mathrm{~cm}$ is quite even (Fig. 3b). In contrast, trees exceeding $65 \mathrm{~cm} \mathrm{DBH}$ are not present in medium forest patches, while the DBH class 35-40 $\mathrm{cm}$ shows a marked peak in the graph (Fig. 3c). In small forest patches, no such peak can be seen (Fig. 3d). In the case of edges and grasslands, trees larger than $5 \mathrm{~cm} \mathrm{DBH}$ are extremely rare (Fig. 3e-g).

$95 \%$ of the exotic tree individuals were Celtis occidentalis, but Ailanthus altissima, Koelreuteria paniculata, Pinus sylvestris, Prunus armeniaca, P. serotinus and Robinia pseudo-acacia were also present. $99.56 \%$ of all exotic trees were in the smallest DBH class, where the number of exotic trees by far exceeded that of the native ones in most habitats (Table 3 ). South-facing edges and grasslands proved to be less suitable for the establishment and survival of exotic species. Also, exotic trees were less numerous in all of the larger DBH classes (Table 3). There were three exotic species that were present in DBH classes larger than $5 \mathrm{~cm}$ : Celtis occidentalis, Pinus sylvestris and Robinia pseudo-acacia.
The results of the three DCA-ordinations were almost exactly the same; therefore, only the analysis using the smallest $(0-5 \mathrm{~cm})$ DBH class is shown (Fig. 4). The DCA confirmed that the study area consists of heterogenous habitats, with a high variation of species composition and abundance characteristics. Large forest patches, medium forest patches and grasslands were the most distinct from one another. In contrast, south-facing edges and small forest patches proved to be relatively similar. North-facing edges were located a bit farther away from this latter group in the scattergram.

\section{Discussion}

One of the main findings of the present study is that the landscape history of the study area provides a good explanation for the actual species composition of the forest and grassland patches reported in earlier analyses. Our landscape historical analysis shows that grasslands must have existed continuously in the region, ensuring the survival of grassland species. This is why there are more grassland-related species than forest-related ones (Erdös et al. 2013a), and why grasslands harbor more rare and endemic species than forests (Erdős et al. 2014). Forests have not been continuously present: there was a lack of forests from at least the $15^{\text {th }}$ century to the $19^{\text {th }}$ century, although there were some small for- 


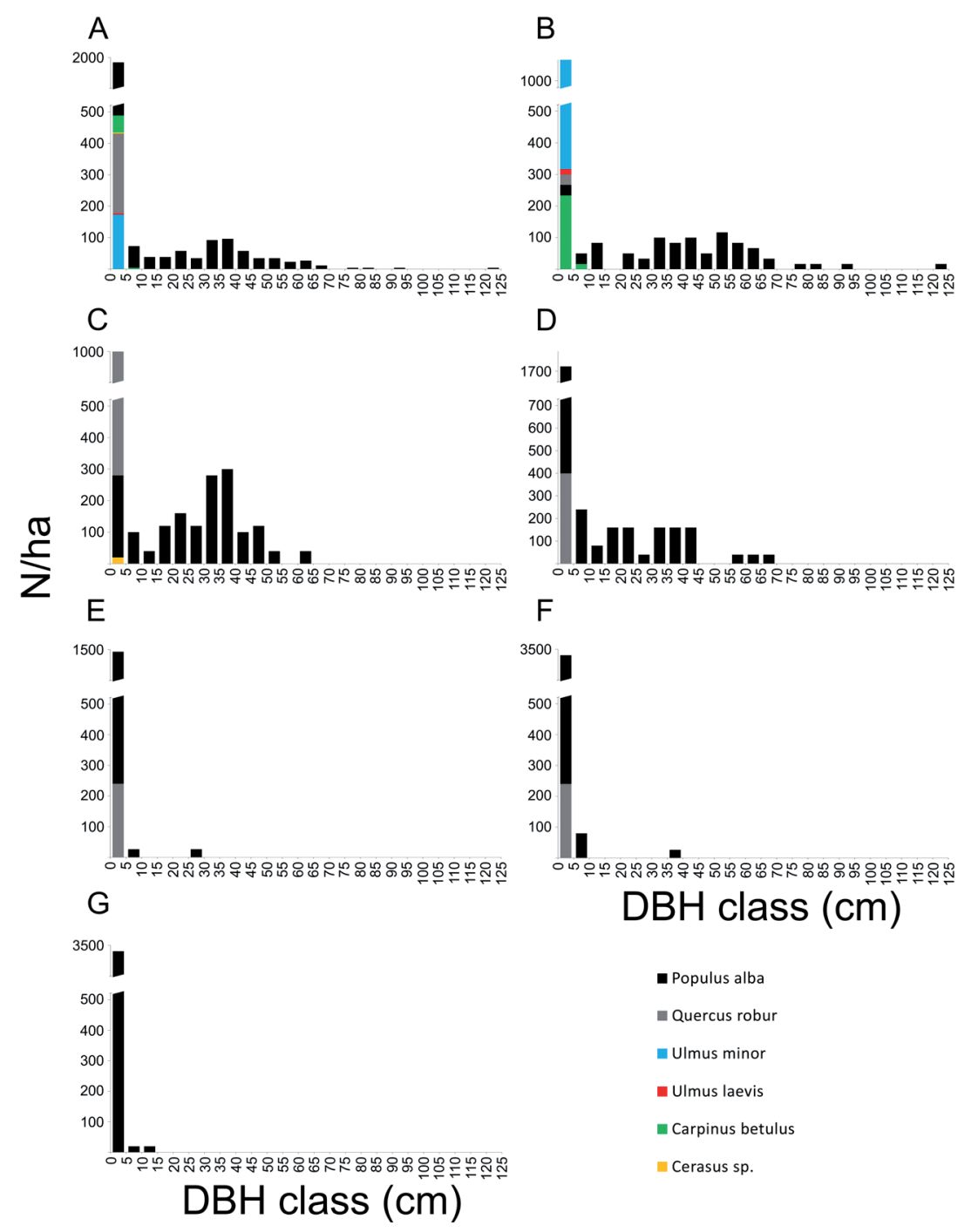

Figure 3. DBH class frequency distribution of the native tree species of the forest reserve. A) total study area, B) large forest patches, C) medium forest patches, D) small forest patches, E) north-facing edges, F) southfacing edges, G) grasslands.

Figure 4. DCA ordination scattergram of the six habitats plus the total study area, based on the log-transformed numbers of tree species in the smallest DBH-class. TSA: total study area, LF: large forest patches, MF: medium forest patches, SF: small forest patches, NE: north-facing edges, SE: southfacing edges, G: grasslands. Eigenvalues of the first two axes were 0.2605 and 0.1913 , respectively. 
est patches, shrubs and individual scattered trees. Moreover, tree density was probably higher in and around settlements. Generalist forest species are able to survive even under individual trees situated in a grassland matrix (personal observation), but specialists and more sensitive species have considerably lower chances to survive in such a landscape. As a consequence, there are relatively many indifferent and exotic plants among the typical forest-related species (Erdős et al. 2013a). Our results are in good agreement with the study of Palo et al. (2008), who found that the species composition in Estonian forests markedly differed between sites where forests have been present continuously and sites where forests were absent for a certain period of time.

Some earlier studies found that the number of forestrelated species decreases towards the southeastern parts of the Danube-Tisza Interfluve, where our study area is located (Fekete et al. 2010, Kovács-Láng et al. 2000). Although the slightly warmer and dryer climate may partly be responsible for this phenomenon (cf. Kun 2001), our results clearly support the hypothesis of Fekete et al. (2010) claiming that vegetation history has a major role in explaining present patterns.

We found that the proportion of forests increased slightly during the last six decades. In extrazonal forest-steppes of the south facing slopes of mountain areas in the Pannonian biogeographical region, forest cover usually increases at the expense of grasslands rapidly (e.g., Centeri et al. 2009, Erdős et al. 2013c). In most of these cases, the treeless period ended a few decades ago when grazing ceased. The rapid forest encroachment probably shows that extrazonal forest-steppes are far from a dynamic equilibrium. In contrast, the treeless period ended much earlier in our study area. Thus, forest cover might be near to its potential maximum, resulting in a very low forest expansion rate. An alternative explanation for the slow forest increase might be provided by the different environmental parameters, i.e., the higher aridity of sandy forest-steppes. At present, grassland patches do not seem to be threatened by forest expansion. If, however, forest encroachment continues, a moderate grazing may be necessary to prevent the closure of gaps and grassland patches, as suggested by Haraszthy (2014).

Although the net change in forest vs. grassland cover was low, a considerable area changed its state during the last sixty years: either from forest to grassland, or from grassland to forest (Fig. 2, Table 1). It was hypothesized by Jakucs (1972) that forest patches gradually open up and develop into grasslands, while shrubs and trees establish in grasslands and gradually turn them into forests. However, the original hypothesis applied only to extrazonal forest-steppes of hilly and mountainous regions. Our results show that to a certain extent, it may also be valid for sandy forest-steppes of the Great Hungarian Plain. However, it should be noted that the overwhelming majority of the study area remained in the same category (i.e., forest or grassland), despite the relatively long period analysed. Thus, in most parts of the area, forest and grassland patches are stable, in accordance with the results of Bodrogközy $(1957,1982)$. He claimed that edaphic parameters inhibit forest expansion because the buried forest soil inherited from the ancient oak forests acts as a strong in- herent abiotic constraint, preventing forest expansion: sandy soils without a buried forest soil cannot support full-grown trees, at least not under the present semiarid conditions. It seems that stability dominates the studied forest-grassland mosaic $(72.45 \%$ of the study area), but in some parts, dynamic processes also operate simultaneously $(27.55 \%$ of the study area).

The cyclic dynamics may be explained by the land-use changes and other human-related phenomena. The original hypothesis of Fekete (1992) on the stability of sandy forestgrassland mosaics described a natural ecosystem, without human influence. If, however, human activity is considered, this may help understand current observed dynamics. More specifically, the cessation of grazing allows the forest patches to expand and re-occupy areas that were forested earlier (prior to grazing). The present dominance of $P$. alba may also contribute to this process: its exceptional clonal spreading capacity and tolerance to harsh conditions (Majer 1968) allow this species to occupy areas which may have not been forests earlier. On the other hand, drying conditions (also a result of local and global human activity, e.g., water regulation and global warming) favor grasslands, possibly explaining forest retreat in the driest places. It can be concluded that the observed cyclic dynamics may be a result of past and current human activity, and not necessarily an inherent feature of the sandy forest-steppes.

Our analysis revealed that habitat heterogeneity has a strong influence on tree establishment and survival. Forest patches of different size, differently exposed edges and grasslands provide different habitats for the tree species (Figs. 3-4). Although P. alba dominates all habitats, other native and exotic species favor mainly large patches (Table 3 ). Moreover, DBH class ditribution also differs considerably among the different habitats (Fig. 3).

Populus alba is known for tolerating extremely hot and dry conditions (Majer 1968, Kopecky 1978). In our study area, $P$. alba individuals are present even in the dryest habitats (edges and grasslands), but they rarely reach large DBH classes (Fig. 3e-g). These results are in good agreement with the observations of Bodrogközy (1982), who described a 'dwarf forest'consisting of ca. 1-1.5 m high P. alba trees in the study area. This 'dwarf forest' is a successional dead-end, where soil and microclimatic conditions prevent the full development of trees. Similarly, Fekete (1992) stated that xeric sandy grasslands usually do not develop into forests under the present climatic conditions. While this may be true in most cases, our results from the aerial photo analysis show that sometimes $P$. alba is able to become full-grown, gradually turning certain grassland sections into a forests. The explanation for this might be the difference between $Q$. robur and P. alba: while it is highly possible that soil parameters and other environmental factors present serious environmental constraints, acting as a barrier against oak penetration into grasslands, the very same barrier can occasionally be broken through by $P$. alba individuals.

We found that Quercus robur seedlings and saplings cannot develop into mature trees under present conditions 
(Fig. 3). It is assumed that the current forest has developed from an ancient oak forest, but $P$. alba has gradually replaced Q. robur in the canopy layer (Bodrogközy 1957). The extraordinary ability of $P$. alba to spread clonally (Majer 1968, Rédei 2010) probably provided the species with a considerable resilience against human disturbances such as cutting, fire or grazing. Currently, the sinking groundwater level (Zsákovics et al. 2007) as well as warmer temperature and decreasing precipitation (Kertész and Mika 1999) also favor $P$. alba because it is better adapted to such conditions than $Q$. robur (Majer 1968). It has been reported from the region that even mature oak trees are not able to survive, probably due to warming and drying conditions (Molnár et al. 2012).

It has been shown that co-occurring tree species react differently to the very same environmental changes (e.g., Granda et al. 2013). The capacity of $P$. alba to survive major human interventions through its clonal spreading and its better tolerance against harsh conditions explain its current dominance over $Q$. robur and other tree species. It is unlikely that the status of the two species will change in the near future, although it is possible that the canopy layer of the studied forest patches will become more and more open if the drying and warming trend continues.

We found relatively high numbers of exotic trees, especially for the smallest DBH class (Table 3). Although the number of exotic trees was lower in the larger DBH classes, and edges and grasslands seemed to have a considerable resistance against exotics, their presence should be regarded as undesirable. In the mid-20 $0^{\text {th }}$ century, exotic trees used to be less abundant than they are now, as suggested by the survey of Bodrogközy (1957): in ten coenological relevés, he did not find a single exotic species.

The three exotics reaching higher DBH classes (Celtis occidentalis, Pinus sylvestris and Robinia pseudo-acacia) should be considered a serious threat. Moreover, C. occidentalis and $R$. pseudo-acacia belong to the most dangerous invasive species in the Pannonian biogeographical region, having the capacity to totally transform and disrupt natural communities (Balogh et al. 2004). In sandy forest-steppes, the presence of invasives is especially hazardous (Haraszthy 2014). C. occidentalis can grow in very dry habitats, and it may develop into full-grown trees even in the harshest sandy regions (Bartha and Csiszár 2006). R. pseudo-acacia may be even more dangerous, due to its permanent seed bank in the soil and its resistance against various extirpation methods (Bartha et al. 2006). The presence of the exotic trees in the nature reserve near Ásotthalom is partly a consequence of the small territory of the protected area. To make things worse, the reserve does not have a buffer zone and is surrounded by tree plantations (some of them native, some non-native). From a nature conservation perspective, it would be highly necessary to enlarge the protected area. Given the good regeneration capacity of the sandy plant communities (Bölöni et al. 2011) and the availability of propagule sources, the reconstruction of a near natural buffer zone would be possible within a few decades. In fact, some of the original species pool can survive under the tree plantations (personal observa- tion). At the very least, the non-native tree plantations adjacent to the protected area should be replaced by native plantations. Furthermore, monitoring surveys should be carried out to track changes in vegetation. Since the nature reserve near Ásotthalom represents one of the most threatened vegetation types in the Pannonian biogeographical region (Kovács-Láng et al. 2000, Molnár et al. 2012, Haraszthy 2014), every measure must be taken to ensure its long-term survival.

Acknowledgements. This research was supported by the European Union and the State of Hungary, co-financed by the European Social Fund in the framework of TÁMOP 4.2.4. A/2-11-1-2012-0001 'National Excellence Program'. We are thankful for the Inspectorate for Environment and Nature Conservation for allowing us the field studies in the protected area.

\section{References}

Ambrózy, P. and F. Kozma. 1990. Dorozsma-Majsai-homokhát. Éghajlat [Climate of the Dorozsma-Majsa sand region]. In: S. Marosi and S. Somogyi (eds.), Magyarország kistájainak katasztere I [Cadaster of the Basic Landscape Units of Hungary I]. MTA Földrajztudományi Kutató Intézet, Budapest. pp. 84-85 (in Hungarian).

Archer, S., C. Scifres, C.R. Bassham and R. Maggio. 1988. Autogenic succession in a subtropical savanna: conversion of grassland to thorn woodland. Ecol. Monogr. 58: 111-127.

Balogh, L., I. Dancza and G. Király. 2004. A magyarországi neofitonok időszerü jegyzéke és besorolásuk inváziós szempontból [The actual list of the Hungarian neophytes and their classification according to their invasiveness]. In: B. Mihály and Z. Botta-Dukát (eds.), Özönnövények [Invasive plants]. Természetbúvár Alapítvány Kiadó, Budapest. pp. 61-92 (in Hungarian).

Bartha, D. and Á. Csiszár. 2006. Nyugati ostorfa (Celtis occidentalis L.) [Common hackberry (Celtis occidentalis L.)]. In: Z. BottaDukát and B. Mihály (eds.), Özönnövények II [Invasive plants II]. Természetbúvár Alapítvány Kiadó, Budapest. pp. 361-374 (in Hungarian).

Bartha, D., Á. Csiszár and V. Zsigmond. 2006. Fehér akác (Robinia pseudoacacia L.) [Black locust (Robinia pseudoacacia L.)]. In: Z. Botta-Dukát and B. Mihály (eds.), Özönnövények II [Invasive plants II]. Természetbúvár Alapítvány Kiadó, Budapest. pp. $37-$ 67 (in Hungarian).

Bartha, S., G. Campetella, M. Kertész, I. Hahn, Gy. Kroel-Dulay, T. Rédei, A. Kun, K. Virágh, G. Fekete and E. Kovács-Láng. 2011. Beta diversity and community differentiation in dry perennial sand grasslands. Ann. Bot.1: 9-18.

Bartha, S., G. Campetella, E. Ruprecht, A. Kun, J. Házi, A. Horváth, K. Virágh and Zs. Molnár. 2008. Will interannual variability in sand grassland communities increase with climate change? Community Ecol. 9: 13-21.

Bátori, Z., L. Erdős, V. Cseh, Cs. Tölgyesi and E. Aradi. 2014. Adatok Magyarország flórájához és vegetációjához I. [Data to the flora and vegetation of Hungary I]. Kitaibelia 19: 89-104 (in Hungarian).

Bél, M. 1984. Csongrád és Csanád megye leirása [Description of Csongrád and Csanád counties]. Móra Ferenc Múzeum, Szeged (in Hungarian). 
Biró, M. and Gy. Gulyás. 1999. A Duna-Tisza köze tájhasználati- és élőhelytérképe a 19. században [Habitat and land-use map of the Danube-Tisza Interfluve in the 19th century]. In: Zs. Molnár (ed.), A Kiskunság száraz homoki növényzete [Sanddunes in Hungary]. Természetbúvár Alapítvány Kiadó, Budapest. p. 32 (in Hungarian).

Bodrogközy, Gy. 1957. Die Vegetation der Weisspappel-Haine in dem Reservat "Emlékerdő" bei Szeged-Ásotthalom. Acta Biol. Szeged. 3: 127-140.

Bodrogközy, Gy. 1982. Hydroecology of the vegetation of sandy forest-steppe character in the Emlékerdő at Ásotthalom. Acta Biol. Szeged. 28: 13-39.

Borhidi, A. 1993. Characteristics of the climate of the Danube-Tisza Mid-Region. In: J. Szujkó-Lacza and D. Kováts (eds.), The flora of the Kiskunság National Park I. Hungarian Natural History Museum, Budapest. pp. 9-20.

Borhidi, A. 1995. Social behaviour types, the naturalness and relative ecological indicator values of the higher plants in the Hungarian Flora. Acta Bot. Hung. 39: 97-181.

Borhidi, A., B. Kevey and G. Lendvai. 2012. Plant Communities of Hungary. Academic Press, Budapest.

Born, I. and J.J. Ferber. 1777. Travels through the Bannat of Temeswar, Transylvania, and Hungary, in the year 1770, and mineralogical history of Bohemia. J. Miller, London.

Bölöni, J., Zs. Molnár and A. Kun. 2011. Magyarország élöhelyei [Habitat types of Hungary]. MTA ÖBKI, Vácrátót (in Hungarian)

Brook, B.W. and D.M.J.S Bowman. 2006. Postcards from the past: charting the landscape scale conversion of tropical savanna to closed forest during the 20 $0^{\text {th }}$ century. Landscape Ecol. 21: 12531266

Centeri, Cs., E. Herczeg, M. Vona, K. Balázs and K. Penksza. 2009. The effects of landuse change on plant-soil-erosion relations, Nyereg Hill, Hungary. J. Plant Nutr. Soil Sci. 172: 586-592.

Chiarucci, A., M.B. Araújo, G. Decocq, C. Beierkuhnlein and J.M. Fernández-Palacios. 2010. The concept of potential natural vegetation: an epitaph? J. Veg. Sci. 21: 1172-1178.

Duguy, B. and V.R. Vallejo. 2008. Land-use and fire history effects on post-fire vegetation dynamics in eastern Spain. J. Veg. Sci. 19: $97-108$.

Erdős, L., R. Gallé, L. Körmöczi and Z. Bátori. 2013a. Species composition and diversity of natural forest edges: edge responses and local edge species. Community Ecol. 14: 48-58.

Erdős, L., V. Cseh and Z. Bátori. 2013b. New localities of protected and rare plants in southern Hungary. Tiscia 39: 17-21.

Erdős, L., D. Cserhalmi, Z. Bátori, T. Kiss, T. Morschhauser, B. Benyhe and A. Dénes. 2013c. Shrub encroachment in a woodedsteppe mosaic: combining GIS methods with landscape historical analysis. Appl. Ecol. Environ. Res.11: 371-384.

Erdős, L., Cs. Tölgyesi, M. Horzse, D. Tolnay, Á. Hurton, N. Schulcz, L. Körmöczi, A. Lengyel and Z. Bátori. 2014. Habitat complexity of the Pannonian forest-steppe zone and its nature conservation implications. Ecol. Complex. 17: 107-118.

Farkas, J. (ed.) 1985. Szeged története 2 [The history of Szeged 2]. Somogyi Könyvtár, Szeged (in Hungarian).

Fekete, G. 1992. The holistic view of succession reconsidered. Coenoses 7: 21-29.

Fekete, G., Zs. Molnár, A. Kun and Z. Botta-Dukát. 2002. On the structure of the Pannonian forest steppe: grasslands on sand. Acta Zool. Hung. 48: 137-150.

Fekete, G., I. Somodi and Zs. Molnár. 2010. Is chorological symmetry observable within the forest steppe biome in Hungary? A demonstrative analysis of floristic data. Community Ecol. 11: 140-147.

Fekete, G., Zs. Molnár, E. Magyari, I. Somodi and Z. Varga. 2014. A new framework for understanding Pannonian vegetation patterns: regularities, deviations and uniqueness Community Ecol. 15: 12-26.

Gál, A. 2011. A tartós szegfü (Dianthus diutinus) felmérése a Kiskunsági és a Duna-Ipoly Nemzeti Park Igazgatóságok területén.[Survey of Dianthus diutinus in the Kiskunság and the Danube-Ipoly National Parks]. Rosalia 6: 269-277 (in Hungarian).

Gaskó, B. 2009. Csongrád megye természetes és természetközeli élőhelyeinek védelméröl II [On the protection of natural and seminatural habitats in Csongrád county II]. Studia Nat. 5: 5-486 (in Hungarian)

Gombocz, E. (ed.) 1945. Diaria itinerum Pauli Kitaibelii auf Grund originaler Tagebücher zusammengestellt. Natural History Museum, Budapest.

Granda, E., J.J. Camarero, T.E. Gimeno, J. Martínez-Fernández and F. Valladares. 2013. Intensity and timing of warming and drought differentially affect growth patterns of co-occurring Mediterranean tree species. Eur. J. For. Res. 132: 469-480.

Gusev A.P. 2014. Land-use history as a factor of the contemporary state of a plant cover: An example from southeastern Belarus. Contemp. Probl. Ecol. 7: 182-186.

Hammer, Ø., D.A.T. Harper and P.D. Ryan. 2001. PAST: Paleontological statistics software package for education and data analysis. Paleontol. Electron. 4: 1-9.

Haraszthy, L. (ed.) 2014. Natura 2000 fajok és élöhelyek Magyarországon [Natura 2000 species and habitat types in Hungary]. Pro Vértes Közalapítvány, Csákvár (in Hungarian).

Härdtle, W. 1995. On the theoretical concept of the potential natural vegetation and proposals for an up-to-date modification. Folia Geobot Phytotax 30: 263-276.

Hill, M.O. and H.G. Gauch. 1980. Detrended Correspondence Analysis: an improved ordination technique. Vegetatio 42: 4758.

Jakucs, P. 1972. Dynamische Verbindung der Wälder und Rasen. Akadémiai Kiadó, Budapest.

Juhász, A. 2008. Állattartás a közlegelőkön, pásztorkodás [Grazing activity on pastures]. In: J. Arany (ed.), Ásotthalom krónikája [The history of Asotthalom]. Ásotthalom Község Önkormányzata, Ásotthalom. pp. 139-150 (in Hungarian).

Karácson, I. (ed.) 1908. Evlia Cselebi török világutazó magyarországi utazásai 1660-1664 [Travels of Evlia Cselebi in Hungary between 1660 and 1664]. Akadémiai Kiadó, Budapest (in Hungarian).

Kerkápoly, G. 1954. A Szeged környéki homokfásítás története és tanulságai [History of forest plantations on sand near Szeged]. Az Erdő 3: 433-438 (in Hungarian).

Kerner, A. 1863. Das Pflanzenleben der Donauländer. Verlag der Wagner'schen Universitäts-Buchhandlung, Innsbruck.

Kertész, A. and Mika, J. 1999. Aridification, climate change is Southeastern Europe. Phys. Chem. Earth Pt. A 24: 913-920.

Kiss, A. 2008. A határ természetföldrajzi jellemzése [Characteristics of the natural environment of Ásotthalom]. In J. Arany (ed.), Ásotthalom krónikája [The history of Ásotthalom]. Ásotthalom Község Önkormányzata, Ásotthalom. pp. 9-20 (in Hungarian).

Kiss, F. 1911. Az alföldi laza talajú erdők [Sandy forests of the Hungarian Plain]. Erdészeti Lapok 50: 71-80 (in Hungarian). 
Kiss, F. 1915. Szeged és környéke homokjának fás növényzetéről [On the sandy forest vegetation near Szeged]. Erdészeti Lapok 54: 535-539 (in Hungarian).

Kopecky, F. 1978. Rezgő és fehér nyárak fajcsoport [Common aspen and silver poplar]. In: B. Keresztesi (ed.), A nyárak és a füzek termesztése [Poplar and Willow Plantations]. Mezőgazdasági Kiadó, Budapest. pp. 30-33 (in Hungarian).

Kovács, J. 2011. Radiocarbon chronology of Late Pleistocene large mammal faunas from the Pannonian basin (Hungary). Bull. Geosci. 87: 13-19.

Kovács-Láng, E., Gy. Kröel-Dulay, M. Kertész, G. Fekete, S. Bartha, J. Mika, I. Dobi-Wantuch, T. Rédei, K. Rajkai and I. Hahn. 2000. Changes in the composition of sand grasslands along a climatic gradient in Hungary and implications for climate change. Phytocoenologia 30: 385-407.

Kun, A. 2001. Analysis of precipitation year types and their regional frequency distributions in the Danube-Tisza Mid-Region, Hungary. Acta Bot. Hung.43: 175-187.

Lengyel G. 1915. A királyhalmi magyar királyi külső erdészeti kísérleti állomás területe növényzetének ismertetése [Vegetation of the forestry station near Királyhalom]. Erdészeti Kisérletek 17: 50-73 (in Hungarian).

Loidi, J. and F. Fernández-González. 2012. Potential natural vegetation: reburying or reboring? J. Veg. Sci. 23: 596-604.

Lunt, I.D. and P.G. Spooner. 2005. Using historical ecology to understand patterns of biodiversity in fragmented agricultural landscapes. J. Biogeogr. 32: 1859-1873.

Magyari, E.K., J.C. Chapman, D.G. Passnore, J.R.M. Allen, J.P Huntley and B. Huntley. 2010. Holocene persistence of wooded steppe in the Great Hungarian Plain. J. Biogeogr. 37: 915-935.

Majer, A. 1968. Magyarország erdőtársulásai [Forest communities of Hungary]. Akadémiai Kiadó, Budapest.

Ministry of Defense Map Archives. 2004. The first military survey 1782-1785. Arcanum, Budapest.

Ministry of Defense Map Archives. 2005. The second military survey 1819-1869. Arcanum, Budapest.

Molnár, Zs. and M. Biró. 2010. A néhány száz évre visszatekintő, botanikai célú történeti tájökológiai kutatások módszertana [Methods in land-use historical researches with a botanical emphasis]. In: P. Szilassi and L. Henits (eds.), Tájváltozás értékelési módszerei a XXI. században. [Methods for Land-use Analyses in the 21st Century]. JatePress, Szeged. pp. 151-180 (in Hungarian).

Molnár, Zs., M. Biró, S. Bartha and G. Fekete. 2012. Past trends, present state and future prospects of Hungarian forest-steppes.
In: M.J.A. Werger and M.A. van Staalduinen (eds.), Eurasian Steppes. Springer, Berlin. pp. 209-252.

Ödman, A.M. and P.A. Olsson. 2014. Conservation of sandy calcareous grassland: What can be learned from the land use history? PLoS One 9: e90998.

Palo, A., M. Linder, J. Truu and Ü. Mander. 2008. The influence of biophysical factors and former land use on forest floristic variability on Saaremaa and Muhu islands, Estonia. J. Nat. Conserv. 16: 123-134.

Pazonyi, P. 2004. Mammalian ecosystem dynamics in the Carpathian Basin during the last 27.000 years. Palaeogeogr. Palaeocl. 212: 295-314.

Rédei, K. 2010. Ültetvényszerü fatermesztés [Forest plantations]. Debreceni Egyetemi Kiadó, Debrecen (in Hungarian).

Reizner, J. 1900. Szeged története IV [The history of Szeged IV]. Szeged Szabad Királyi Város, Szeged (in Hungarian).

Simon, T. 2000. A magyarországi edényes flóra határozója, 4th ed [Vascular Flora of Hungary]. Nemzeti Tankönyvkiadó, Budapest.

Silva, J.F., A. Zambrano and M.R. Fariñas. 2001. Increase in the woody component of seasonal savannas under different fire regimes in Calabozo, Venezuela. J. Biogeogr. 28: 977-983.

Somodi, I., K. Virágh and R. Aszalós. 2004. The effect of the abandonment of grazing on the mosaic of vegetation patches in a temperate grassland area in Hungary. Ecol. Complex. 1: 177-189.

Szamota, I. 1891. Régi utazások Magyarországon és a Balkánfélszigeten [Old travels in Hungary and the Balkans]. Franklin Társulat, Budapest (in Hungarian).

Szüts, M. 1914. Szeged mezögazdasága [Agriculture of Szeged]. Dugonics Társaság, Szeged (in Hungarian).

Vedres, I. 1825. A sívány homokság használhatása [How to use the sandy areas]. Grünn Orbán, Szeged (in Hungarian).

Vera, F.W.M. 2000. Grazing Ecology and Forest History. CABI Publishing, Wallingford.

Zólyomi, B. 2007. Magyarország természetes növénytakarója [Natural vegetation of Hungary]. In M. Járai-Komlódi (ed.), Pannon enciklopédia: Magyarország növényvilága, $3 r d$ ed. Urbis, Budapest. pp. 156-157 (in Hungarian).

Zsákovics, G., F. Kovács, A. Kiss and E. Pócsik. 2007. Risk analysis of the aridification-endangered sand-ridge area in the DanubeTisza Interfluve. Acta Climatol. Chorol. Univ. Szeged. 40-41: 169-178.

Received August 5, 2014

Revised November 15, 2014 Accepted February 23, 2015 